\title{
Telling life stories using creative methods in qualitative interviews
}

Signe Ravn

University of Melbourne

This is the accepted version of the book chapter, ie the final version before layout and typesetting. Some minor changes may have occured in the proof stages.

The full reference is: Ravn, S. (2019): 'Telling life stories using creative methods in qualitative interviews'. In: Research methods for auto/biography studies, eds. Barnwell, A. and Douglas, K. London: Routledge.

\section{Introduction}

Studying people's life stories using qualitative interviews is a well-established approach in the social sciences and beyond, whether in the form of actual biographical interviews or through a focus on select parts of individuals' lives and the stories they tell about this. Such methods, and their resulting representations, have also been subject to critique from sociologists, perhaps most famously Pierre Bourdieu's famous critique of the traditional life history as 'a biographical illusion' (Bourdieu). According to Bourdieu, the life history makes the chaos of 'life as lived' look like a chronological and straightforward trajectory with a clear purpose or project; but this is an illusion. As Margaretha Järvinen writes, 'a biography is a story put together with the help of culturally available instruments and ingredients' (372). A central task for the life writing sociologist is therefore also to shed light on these 'cultural instruments', or in other words, illuminate the broader socio-cultural context in which a certain life story is told to build an understanding of how this shapes the story that emerges. This can also make us aware of the constructed character of such life stories; a construction which the method in question itself is part of. With this in mind, we can think of creative methods as holding the potential to construct other stories. Thus, using creative methods in research interviews can be one way for life writing scholars and those writing auto/biography to discover alternative, or otherwise untold, life narratives.

In recent years, the literature on qualitative methodologies has developed significantly as participatory and creative methods have experienced immense popularity among researchers. While the motivations for applying such methods differ, they can be seen as part of a general attempt at breaking away from 'the standard interview' (cf. Bagnoli) and explore the potential of other methodological approaches. They are often also embedded in attempts to address and shift the power dynamics inherent in the research encounter. Helene Hjort Oldrup and Trine Agervig Carstensen differentiate between neo-realist approaches and constructivist-interactionist approaches to the data that these methods produce. That is, scholars either apply creative methods to get 'closer' to the experiences of the topic under study, or to approach the topic under study from a different, but not better or more 'true', perspective. In line with the sociological reflections on the status of biographical data mentioned above, I approach creative methods from a constructivist point of view, as methods that allow us to inquire into other dimensions of people's life stories. Giving a full overview of the broad range of methods lies beyond the aims of this chapter. Instead I will focus on three broad types of methods - life charts, mapping methods and 
music-focused methods - to illustrate the potential of each of these for studying life narratives. As Maggie O'Neill \& Phil Hubbard put it, 'representing life history/biographical narratives through art forms can create multi-vocal, dialogic texts which make visible emotional structures and inner experiences as sensuous knowledge' (Kuzmics 9, cited in O'Neill \& Hubbard 47). Hence, the focus of this chapter is on how creative methods can assist interdisciplinary life narrative researchers in bringing forward other aspects of life stories than those favoured by the traditional, biographical interview.

\section{Life charts}

The creative method that comes closest to a traditional life history or biographical interview is what is known as life charts, sometimes also called life grids or timelines. Life charts are used in qualitative interviews to visually represent the participant's biography, or aspects thereof. Depending on epistemological approach, the life chart can be used as a means to uncovering factual events in a person's life, getting an overview of the chronology of such events or even 'validating' information from other sources (e.g, Berends), or it can feature as a way of investigating what individuals see as the key events in their lives. This latter approach is often underpinned by analytical concepts such as turning points (Elder) or critical moments (Thomson et al), i.e., events that are seen as having impacted one's life trajectory or sense of self. Life charts have been used across disciplines and for a number of purposes, not necessarily related to biographical research, for instance youth loneliness (Thomsen), substance use (Berends) and weight loss (Sheridan et al). In my current research project, a three-year study of the everyday lives and imagined futures of young Australian women who have left school early, I work with life charts to produce data on what the young women themselves see as important for how their lives look today. What comes through here is that this task not only captures 'traditional' life course events (cf. Elder) such as marriage, parental illness or leaving the parental home, but also events such as going to see a musical, or meeting a new friend for the first time. Embedding such events in a biographically oriented project the central analytical question that comes to the fore is why these events, and not others, have made it onto the life chart, how they sit in relation to the broader biography and how they shape the participant's identity today. What must also be kept in mind, though, is how life charts are likely to give prominence to a certain 'biography' as they are likely to produce data on ruptures and changes rather than continuity and stability. This should be taken into account when interpreting the charts - by approaching it as an 'organising principle' (cf. Adriansen) in itself - but also ideally be picked up on in other parts of the interview to gain perspective on what has happened between these turning points or critical moments. In other words, life charts seem to be the most productive when designed as one element as part of a longer, qualitative interview, allowing the researcher to probe further into the resulting life chart.

\section{Mapping methods}

Mapping methods is an umbrella term for a range of methods that are used across different disciplines. One cluster of mapping methods focus on social networks and seek to map for instance the quantity and quality of an individual's social relations, or social capital. This is for instance the case with the what is termed the 'hierarchical mapping technique' (Antonucci), which involves different variations of locating family, friends and acquaintances in concentric circles that are closer or further away from the participant, depending on the nature of the relation. While these can have a longitudinal or life course dimension to them 
(e.g., Pahl \& Spencer), they are typically not used for generating biographical data. Another cluster of mapping methods are more concerned with maps in a geographical sense and use mapping methods to create a visual representation of for instance uses of urban spaces (Duff; Clark; Travlou et al), or to produce data on spaces that are hard to access for the researcher (Ravn \& Duff). At a first glance, this method is also not linked to analytical interests in biographical aspects of the participants' lives. However, it can be designed to produce insights into life stories that, while not fitting traditional formats, can yield significant insights into how biographies relate to space and place (e.g., Taylor; O'Neill \& Hubbard). As an example, in my current research I am asking the participants to first draw a map of their neighbourhood including places they pass through or in which they spend time. Secondly, I ask them to attach Post-Its with two different colours, one for places they like and one for places they do not like. The dialogue that comes from this task did not only concern their sense of belonging in the present but also has traces this back in time, for instance through talk of places where they used to spend time (e.g., as kids), places that have changed and places that hold certain memories, be they negative or positive. Depending on the population in focus of the research, one can also imagine how this approach can touch on family relations, and family histories in relation to place.

\section{Music}

Creative methods involving music are yet to be further explored and developed. The uses of music so far seem to be parallel to uses of photos, i.e., music is either brought by the researcher and used to stimulate discussion in the interview ('music elicitation') or music is brought by the research participants who have chosen this to tell a certain story ('music voice'). Nicola Allett's research on Extreme Metal fans in the U.K. is an example of the former (Allett). By making participants listen to pieces of metal music in the context of the interview, she aimed to study how music featured in their everyday lives. While Allett's interests were not life histories or biographical experience, her research did produce insights into the feelings and memories that the music brought to the fore in the interview situation. In contrast to Allett's study, 'music voice' as a method was used in a more recent study of the transitions to adulthood among young people, who had grown up in out-ofhome-care in Denmark ${ }^{1}$. Inspired by the work of Sarah Wilson \& Elisabeth-Jane Milne, participants were asked to bring a piece of music that was important to them to the second interview (Ravn \& $\varnothing$ stergaard). Using music in research with an interest in biographical experience rests theoretically on the argument made by Tia DeNora that music is not only a central part of our everyday lives in the present but also that 'music is a medium that can be and often is simply paired or associated with aspects of past experience' (48). Music is closely linked to memory (van Dijck) and while not biographical in a chronological sense, using music as a method can in that sense be seen as a form of memory work (McLeod \& Thomson). This was also the case in the Danish study where the music brought by participants facilitated stories about growing up, (troubled) family relations and identity formation (Ravn \& $\varnothing$ stergaard). This study, however, had its primary focus on the role that music played in the everyday lives of the participants - for instance as a 'technology of the self' (DeNora 53) to help manage difficult emotions - rather than the biographical

\footnotetext{
${ }^{1}$ The Danish study is part of a three-country comparative research project on young people leaving care entitled 'Against all odds', comprising Norway, England and Denmark. The music component was only used in England (PI Professor Janet Boddy, Sussex University) and Denmark, but at the time of writing only the publication on the Danish data is out.
} 
components. Hence, there is scope for innovative designs that draw on the capacities of music and link this to life histories, whether with young people or other populations.

\section{Summing up}

The aim with this brief chapter has been to suggest some alternative ways of exploring life stories through the use of creative methods in the setting of qualitative interviews. These methods are not meant to replace the conventional qualitative interview, but to be used in the context of such interviews. While not in any way suggesting to 'retire' the traditional life history interview, the purpose of this chapter has rather been to suggest ways of supplementing the life stories this produces with other stories. The research findings we get depend on the methods we use; hence using new methods might help us produce new findings; or to add nuances to the findings we get from the conventional qualitative interview. The creative methods presented in this chapter are by no means extensive, and neither are the uses of them described here. For researchers to use any such methods, there are multiple ways of moving forward and adapting these to the research questions and aims of single projects.

\section{Works Cited}

Adriansen, Hanne K. 'Timeline interviews: A tool for conducting life history research.' Qualitative Studies, vol. 3, no. 1, 2012, pp. 40-55.

Allett, Nicola. Sounding Out: Using music elicitation in qualitative research. NCRM Working Paper Series 04/10. Morgan Centre, 2010.

http://eprints.ncrm.ac.uk/2871/1/0410 music elicitation.pdf

Antonucci, Toni C. 'Social support networks: Hierarchical mapping technique.' Generations, vol. 10, no. 4, 1986, pp. 10-12.

Berends, Lynda. 'Embracing the Visual: Using Timelines with In-Depth Interviews on Substance Use and Treatment.' Qualitative Report, vol. 16, no. 1, 2011, pp. 1-9.

Bagnoli, Anna. 'Beyond the standard interview: The use of graphic elicitation and arts-based methods.' Qualitative Research, vol. 9, no. 5, 2009, pp. 547-570.

Boddy, Janet et al. "Navigating precarious times? The experience of young adults who have been in care in Norway, Denmark and England". Journal of Youth Studies, Early online, 2019.

Bourdieu, Pierre. 'The biographical illusion', 1986. Identity: a reader, edited by Paul du Gay et al., Sage, 2000, pp.297-303.

Clark, Alison. 'Multi modal mapmaking with young children: exploring ethnographic and participatory methods'. Qualitative Research, vol. 11, no. 3, 2011, pp. 311-330.

DeNora, Tia. 'Music as a technology of the self.' Poetics, vol. 27, 1999, pp. 31-56. 
Duff, Cameron. 'On the Role of Affect and Practice in the Production of Place'. Environment and Planning D: Society and Space, vol. 28, no. 5, 2010, pp. 881-895.

Elder, Glen. H., Jr. Children of the Great Depression: Social change in life experience. University of Chicago Press, 1974.

Järvinen, Margaretha. 'The Biographical Illusion: Constructing Meaning in Qualitative Interviews.' Qualitative Inquiry, vol. 6, no. 3, 2000, pp. 370-391.

Mannay, Dawn. Visual, Narrative and Creative Research Methods. Application, reflection and ethics. Routledge. 2016

McLeod, Julie \& Rachel Thomson. Researching Social Change. Sage, 2009.

O'Neill, Maggie \& Phil Hubbard. 'Walking, sensing, belonging: ethno-mimesis as performative praxis'. Visual Studies, vol. 25, no.1, 2010, pp. 46-58.

Pahl, Ray \& Liz Spencer. 'Personal Communities: Not Simply Families of 'Fate' or 'Choice', Current Sociology, vol. 52, no. 2, 2004, pp. 199-221.

Ravn, Signe \& Cameron Duff. 'Putting the party down on paper: A novel method for mapping youth drug use in private settings.' Health \& Place, vol. 31, 2015, pp. 124-132.

Ravn, Signe \& Jeanette Østergaard. 'En anden fortælling? Musik som metode i interviews med udsatte unge [A different story? Music as method in interviews with vulnerable youth]'. Metoder i ungdomsforskning [Methods in youth studies], edited by M. Pless \& N. Soerensen. Aalborg University Press, 2018.

Sheridan, Joanna, et al. 'Timelining: visualizing experience.' Qualitative Research, vol. 11, no. 5, 2011, pp. 552-569.

Taylor, Stephanie. 'A place for the future? Residence and continuity in women's narratives of their lives.' Narrative Inquiry, vol. 13, no. 1, 2003, pp. 193-215.

Thomson, Rachel, et al. 'Critical Moments: Choice, Chance and Opportunity in Young People's Narratives of Transition.' Sociology, vol. 36, no.2, 2002, pp. 335-354.

Travlou,Penny, et al. 'Place mapping with teenagers: locating their territories and documenting their experience of the public realm.' Children's Geographies, vol. 6, no. 3, 2008, pp. 309-326.

van Dijck, José. 'Record and hold: popular music between personal and collective memory.' Critical Studies in Media Communication, vol. 23, no. 5, 2006, pp. 357-374.

Wilson, Sarah \& Elisabeth Milne. Young people Creating Belonging. Spaces, Sounds and Sights. University of Stirling, 2013. 



\section{University Library}

\section{- M M N E R VA A gateway to Melbourne's research publications}

Minerva Access is the Institutional Repository of The University of Melbourne

Author/s:

Ravn, S

Title:

Telling Life Stories Using Creative Methods in Qualitative Interviews

Date:

2019

Citation:

Ravn, S. (2019). Telling Life Stories Using Creative Methods in Qualitative Interviews.

Barnwell, A (Ed.). Douglas, K (Ed.). Research Methodologies for Auto/biography Studies, (1), pp.103-108. Routledge.

Persistent Link:

http://hdl.handle.net/11343/294919 